\section{The relationship between organizational learning and sustainable performance: an empirical examination}

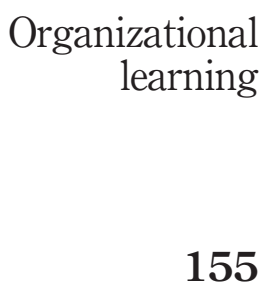

\author{
Anna Zgrzywa-Ziemak and Katarzyna Walecka-Jankowska \\ Department of Management Systems and Organizational Development, \\ Wroclaw University of Science and Technology, Wroclaw, Poland
}

Received 10 May 2020 Revised 28 July 2020 10 September 2020 Accepted 15 September 2020

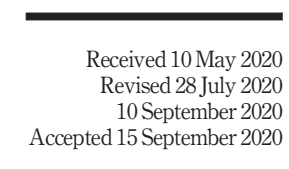

\begin{abstract}
Purpose - The purpose of this study is to investigate the relationship between organizational learning (OL) and business sustainability (BS) and to carry out its empirical examination.

Design/methodology/approach - Extensive literature research was carried out. Then, an empirical study was conducted in 694 Polish and Danish companies. Two phenomena related to OL were adopted: OL processes and organizational learning capability (OLC). BS was examined through the concept of sustainable performance (SP). Research models were tested using structural equation modeling.

Findings - The empirical studies have shown a positive, statistically significant relationship between OL and BS. The research supports the view that the intensification of the OL processes is substantial for BS, whereas the OLC concept is less relevant to the development of $\mathrm{BS}$. The effect of OL on total SP was stronger than on any SP dimension. OL supports the synergies of the results obtained by the organization for the benefit of BS.

Research limitations/implications - The model verification is based on the samples from two countries, and, therefore, the hypothesis requires further verification in different business contexts. In addition, there are different factors influencing BS, which have not been included in the research and should be analyzed in the future.

Originality/value - An in-depth, critical literature analysis shows that the theoretical foundation of the role of OL in shaping BS is fragmented and poorly empirically verified. The value of this paper is the presentation of large-scale empirical studies comparing the relationship between BS and two phenomena: OLC and the OL processes. The results obtained in the course of the research open up new research directions with respect to both the relationship between OL and BS as well as between OL and organizational performance.
\end{abstract}

Keywords Performance, Organizational learning capability, Organizational learning, Business sustainability, Sustainable performance

Paper type Research paper

\section{Introduction}

The concept of business sustainability (BS) is rooted in a broader concept of the sustainable development of the world, which is considered to be one of the most significant and urgent

(C) Anna Zgrzywa-Ziemak and Katarzyna Walecka-Jankowska. Published by Emerald Publishing Limited. This article is published under the Creative Commons Attribution (CC BY 4.0) licence. Anyone may reproduce, distribute, translate and create derivative works of this article (for both commercial and non-commercial purposes), subject to full attribution to the original publication and authors. The full terms of this licence may be seen at http://creativecommons.org/licences/by/4.0/legalcode

The research was financed by the Polish National Science Center as a research project 2017/01/X/ HS4/01485. 
JWL 33,3

challenges that humanity is facing today. Therefore, the solutions promoting BS are becoming particularly important. As pointed out by Smith (2012), there are many opportunities for researchers and practitioners to contribute to the understanding of how organizational learning (OL) may be optimally and systemically introduced and progressed in organizations traveling on a sustainability journey. However, an in-depth critical literature analysis shows that the theoretical foundation of the role of OL in shaping BS is fragmented and, what is particularly well visible, poorly empirically verified.

The primary aim of the paper is to discuss the relationship between OL and BS and to provide its empirical examination.

In the literature, OL issues relate to various phenomena, e.g. learning orientation, the $\mathrm{OL}$ processes, organizational learning capability (OLC), learning organization. In the paper, two concepts are adopted: the OL processes and OLC. The former one is considered to be fundamental for any discussion about OL (Easterby-Smith and Lyles, 2011) while the latter represents the most complex term in the field as it refers to "meta-learning" and takes into account several factors necessary for learning and going beyond the learning processes, including organizational culture, leadership, structure, organizational continuity and strategy (Zgrzywa-Ziemak, 2019a).

BS is a complex multifaceted phenomenon, integrating some - often contradictory and conflicting - aspects (Dyllick and Muff, 2016). It refers to the participation of the business in sustainable development and it is defined as the business's commitment and activities for the benefit of contributing to sustainable development (Zgrzywa-Ziemak, 2019a). In the paper, the notion of sustainable performance (SP) is adopted and developed as the manifestation of the business contribution to sustainable development. The study is, therefore, embedded in a widely discussed and researched problem of the relationship between OL and organizational performance. However, there is no research relating OL to SP.

The current study addresses three main research questions:

$R Q 1$. What effect does OLC have on SP?

$R Q 2$. What effect do the OL processes have on $\mathrm{SP}$ ?

RQ3. Which OL phenomena - OLC or the OL processes - are more relevant to shaping SP?

The study was carried out through the extensive literature review. The empirical research was conducted in 694 companies operating in Poland and Denmark. The descriptive and statistical deduction methods were used.

\section{Literature review}

\subsection{Business sustainability}

In the paper, it is assumed that BS refers to the participation of the business in sustainable development. This is a holistic approach, in which the organization is perceived as "a mesoscale social artifact in need of consideration as a possibly potent means of approaching sustainable development” (Parrish, 2007, p. 848). A sustainable organization creates a significant positive impact on the areas which are critical and relevant to society and the planet (Dyllick and Muff, 2016). Although it has to generate the profit that allows the reconstruction of its potential and further development, the overriding objective of the organization should be the commitment to the development of the broader socio-ecological system (Senge et al., 2010). However, different BS approaches are present, also those referring to the survival and development of the organization itself as a system (Ihlen, 2015). It is especially visible in the instrumental approach in which the creation of the long-term 
shareholder value is recognized as the essence of BS, in which social and environmental concerns are essential in the context of opportunities and risks, benefits and costs which are crucial for building this value (RobecoSAM, 2015). It is also true of the prevailing win-win approach, the essence of which is the simultaneous, synergistic, systematic provision of economic, social and environmental benefits (Sekerka and Stimela, 2011). The win-win approach focuses on finding cost-effective areas for the organization, which are, at the same time, socially and/or environmentally beneficial (Porter and Kramer, 2011). This approach avoids a deeper reflection on the systematic responsibility of the organization; it is based on the current assumption of proceeding by its own interest (Crane et al., 2014). The holistic approach is adopted.

The concepts of BS refer to the organization's objectives - in relation to sustainable development goals (Dyllick and Muff, 2016), processes or activities which constitute BS (Salzmann et al., 2005), the characteristics of a sustainable organization (Smith and Sharicz, 2011) and results - the contribution of organizations to sustainable development (Hart and Milstein, 2003). This study adopts the BS approach based on organizational performance. The notion of SP is developed as the manifestation of the business contribution to the improvement or deterioration of economic, environmental and social conditions, developments and trends at the local, regional or global level (GRI, 2013).

\subsection{Organizational learning}

$\mathrm{OL}$ is one of the core constructs in the organizational theory. The analysis of the definitions offered by many scholars leads to some conclusions about the nature of learning in organizations (Watkins and Kim, 2018; Zgrzywa-Ziemak, 2019a, 2019b). OL:

- is a continuous process, as the changes in the organization and outside of it are continuous (Tsang, 1997);

- occurs under the influence of the interaction between the organization and its environment and as a result of internal aspirations (Dodgson, 1993);

- has the cognitive and social perspectives (Easterby-Smith and Araujo, 1999). The learning process goes beyond information processing (e.g. Huber, 1991), it occurs as a result of social interactions in the natural workplace (Cook and Yanow, 1993);

- is performed by the concurrent processes of the verification of the existing knowledge and the development of the new one (i.e. by concurrent clashes of the exploitation and exploration processes), unlearning is part of learning here (de Holan and Phillips, 2011). The notion of the organizational knowledge is viewed as a complex phenomenon encompassing several levels distinguished with reference to the criterion of the difficulty of their change (Schein, 1992; Schön and Argyris, 1996; Nonaka and Takeuchi, 1995; Dixon, 1997);

- proceeds among different levels: individual, group, organizational and interorganizational levels, and learning on different levels is of a different character (Crossan et al., 1999; Easterby-Smith and Lyles, 2011);

- is inextricably linked to action (learning affects acting and vice versa); however, the results of OL should be viewed more broadly - it might be a change not only of the behaviors of the organization but also of the potential behaviors (Tsang, 1997); and

- is not a fully conscious process. Learning is susceptible to control and direction; however, it also evolves naturally (Shipton and Defillippi, 2011). 
JWL 33,3

Although OL issues relate to various phenomena, e.g. learning orientation, the OL processes, OLC, learning organization, for the present discussion, it is crucial to define the concept of OLC.

Despite the fact that OLC is present in the literature (Ulrich et al., 1993; Dibella et al., 1996; Goh, 2003; Jerez-Gómez et al., 2005; Bhatnagar, 2006; Chiva et al., 2007; Zgrzywa-Ziemak, 2019a), there is no consensus on its definition (Migdadi, 2019). Goh (2003, p. 217) defines OLC quite narrowly from the managerial perspective as "the ability of the organization to implement the appropriate management practices, structures and procedures that facilitate and encourage learning." Alegre and Chiva (2008, p. 315) understood OLC from the resourcebased view; they see it "as a bundle of tangible and intangible resources or skills the firm uses to achieve new forms of competitive advantage." Jerez-Gómez et al. (2005, p. 2) conceptualize OLC broadly as "the capability of an organization to process knowledge - to create, acquire, transfer, and integrate knowledge, and to modify its behaviour to reflect the new cognitive situation, to improve its performance." However, in all these concepts, OLC is arbitrarily linked with the improvement of organizational results. This approach seems to be incoherent and incomplete as it only explains the relationship between learning and positive results while it does not explain the situation in which the result is not positive or expected (Kim and Senge, 1994; Schön and Argyris,1996; Arend and Bromiley, 2009). In the paper, the definition of OLC offered by Zgrzywa-Ziemak (2019a) is adopted, which - like in the proposal of Jerez-Gómez et al. (2005) - relates directly to the changes of organizational knowledge. However, it does not incorporate performance improvements into the concept. OLC is "the ability of the organization to change its knowledge, where the change covers two parallel processes - the verification of the existing knowledge and the development of the new one" (Zgrzywa-Ziemak, 2019a, 2019b, p. 1794). OLC refers to the concepts of OL and the learning organization. Moreover, it is also linked to the concept of meta-learning and refers to the potential of organizations to learn, not to the course of specific processes of OL (Zgrzywa-Ziemak, 2019a, 2019b).

\subsection{Relationship between organizational learning and performance}

It should be emphasized that because of the understanding of BS in the context of the organization's participation in sustainable development, these studies belong to the research on the relationship between OL and organizational performance.

Although from the theoretical point of view, the relationship between OL and organizational performance is neither obvious nor clear (Zgrzywa-Ziemak, 2015), the analysis of several empirical studies allows assuming that OL has an essential impact on organizational performance (Perez Lopez et al., 2005; Prieto and Revilla, 2006; JiménezJiménez and Sanz-Valle, 2011; Goh et al., 2012; Watkins and Kim, 2018). In the present research, $O L$ was measured by different phenomenon: learning orientation (measured mainly by a scale offered by Baker and Sinkula (1999a)); OL processes (mostly four subprocesses of OL suggested by Huber (1991) are used), learning organization (mainly by dimensions of the learning organization devised by Marsick and Watkins (1999) and its simplified version offered by Yang et al. (2004)) and learning organization capability (different scales are adopted, including those developed by Jerez-Gómez et al. (2005), Ya-Hui and Li-Yia (2008), Alegre and Chiva (2008)). What dominates is the studies which confirm the positive influence of OL on overall organizational results (mainly financial), innovation, strategy effectiveness and strategic flexibility, the results of projects and employees' attitudes and behaviors (Goh et al., 2012; Zgrzywa-Ziemak, 2015; Watkins and Kim, 2018). Only a few studies prove that there is no relationship between OL and financial results or that it is not unambiguous (Prieto and Revilla, 2006). Numerous studies show that the 
relationship between learning and performance has an indirect influence (Pesämaa et al., 2013). The mediating role of OL in increasing performance is also investigated and proved (Alegre and Chiva, 2013). Finally, the influence of OL on the improvement of organizational results has been confirmed in numerous cultural contexts and types of organizations in a range of industries and under numerous conditions (Goh et al., 2012; Zgrzywa-Ziemak, 2015; Watkins and Kim, 2018). However, there is no research relating OL to SP.

\subsection{Organizational learning and business sustainability}

The importance of OL for an organizational shift to be more sustainable has already been recognized by scholars (Edwards, 2009; Senge et al., 2010). There are OL concepts which focus on sustainability. Molnar and Mulvihill (2003) propose the term "sustainabilityfocused organizational learning" (SFOL) to describe the early experience of companies that attempt to pursue sustainability or the triple bottom line while making substantial changes to their organizational cultures (five companies pursuing SFOL were analyzed). Siebenhüner and Arnold (2007) use the concept of "sustainability-oriented organizational learning" without defining it. Based on six organizations, they investigated how sustainabilityoriented knowledge is absorbed, generated, disseminated and implemented in the respective organizations and what the causal factors for sustainability-oriented learning processes are. Edwards (2009) formulates an integrative meta-theory for OL and sustainability (in turbulent times). He integrates different stages of sustainable organizing (compliant, efficient, committed and sustaining stage) and multiple loops learning (single, double and triple-loop learning) over time. He identifies basic paradoxes in shaping organizational sustainability. He points to OL as an essential contributor to organizational sustainability development. There are also attempts to define a sustainable learning organization (Velazquez et al., 2011; Toma, 2012; Wilson and Beard, 2014). Although the researchers presume that the concepts associated with OL are essential for the formation of BS, the conceptual solutions in this area are still somewhat fragmented and there is almost no empirical verification of the identified compounds as only single case studies are available.

Furthermore, the role of OL in determining BS is discussed mainly in the context of increasing organization adaptive capabilities to cope with sustainable development challenges. However, such an approach seems to be too limited. Edwards (2009) points out that the organization needs to face the sustainability paradox of embracing the radical change to develop adaptive capabilities while also retaining a coherent identity and stability (in the long-term or even intergenerational perspective). Although the previously mentioned author does not specify what the source of identity and stability could be, the issue is - to a small extent - incorporated in the discussion about the importance of OL for BS. Senge et al. (2010) and Molnar and Mulvihill (2003) argue that in the company, the highest level goals of the development of society and a positive impact on the restoration of the environment must be consistent with the core values. However, their view is not empirically verified. ZgrzywaZiemak (2019a) formulates and empirically verifies the concept of $O L C$, which integrates the dimensions responsible for the permanent change of the organization with organizational continuity built by a shared vision derived from the core values. As a result, this paper exploring the relationship between OL and BS attempts to study the relationship between not only the OL processes and BS but also OLC and BS. Thus, two hypotheses were formulated:

H1. OLC positively affects SP.

H2. The OL processes positively affect SP. 
JWL 33,3

160

It is assumed that in the context of SP, OL should be regarded more as a meta-learning concept (meaning OLC) and not only as the OL processes. However, what was considered particularly relevant was the development of organizational continuity. As a consequence, the following hypothesis was put forward:

H3. The relationship between OLC and SP is stronger than the relationship between the OL processes and SP.

\section{Empirical verification of the relationship between organizational learning and sustainable performance}

The empirical study aimed at verifying the relationships between OL (the OL processes and OLC) and SP.

\subsection{Research methodology}

The research was carried out by means of the survey method. The survey was composed of the questions measuring each of the OLC dimensions (68 items) and those referring to SP (15 items). The questionnaire was supplemented with the characteristics of the enterprise used to determine the structure of the surveyed enterprises (the type of business activity, employment size and the form of ownership). The first part of the questionnaire included the presentation of the purpose of the survey. Moreover, the respondents were asked to answer what they in fact thought the enterprise looked like rather than what it should look like. It was also stressed that the survey should be completed by higher-level managers or other people who have a broad view of the entire enterprise. Furthermore, it was assured that the answers were anonymous. Thanks for participating in the survey were also included. The method of the competent judges was used to verify the accuracy of the items included in the questionnaire already at the drafting stage. The judges, who were academics, senior managers and statisticians, assessed each item of the questionnaire independently.

The studies were conducted in the businesses functioning in two countries which have different approaches to engagement in the issues of sustainable development: in Poland and in Denmark. Thus, the research covered business organizations, employing at least ten people. One survey was filled in by each organization. Higher-level managers or other people who have a broad view of the entire enterprise were the respondents (it was assumed that such a person, in addition to the president and his/her deputy, could be, for instance, an organizational specialist, a business process management specialist and a quality specialist). The studies were carried out at the turn of 2018 and 2019. In total, 694 businesses were examined: 391 businesses operating in Poland and 303 in Denmark. Owing to the purpose of the study, the sample was not representative. First of all, the aim was to obtain numerically

Table 1.

Structure of the enterprises in terms of the employment size

\begin{tabular}{lrrrrrr}
\hline & \multicolumn{3}{c}{ Poland $(n=391)$} & \multicolumn{2}{c}{ Denmark $(n=303)$} & \multicolumn{2}{c}{ Total $(n=694)$} \\
Enterprise size (number of employees) & No. & $(\%)$ & No. & $(\%)$ & No. & $(\%)$ \\
\hline Small enterprises (between 10 and 49) & 126 & 32,2 & 67 & 22,1 & 193 & 27,8 \\
Medium (between 50 and 249) & 86 & 22,0 & 87 & 28,7 & 173 & 24,9 \\
Large (between 250 and 1,000) & 98 & 25,1 & 52 & 17,2 & 150 & 21,6 \\
Very large (over 1,000) & 73 & 18,7 & 82 & 27,1 & 155 & 22,3 \\
Total & 383 & 98,0 & 288 & 95,0 & 671 & 96,7 \\
Source: The authors' own study & & & & & & \\
\hline
\end{tabular}




\begin{tabular}{|c|c|c|c|c|c|c|c|}
\hline \multirow{2}{*}{$\begin{array}{l}\text { European classification of economic } \\
\text { activities }\end{array}$} & \multicolumn{2}{|c|}{ Poland $(n=391)$} & \multicolumn{2}{|c|}{ Denmark $(n=303)$} & \multicolumn{2}{|c|}{ Total $(n=694)$} & \multirow{2}{*}{$\begin{array}{r}\text { Organizational } \\
\text { learning }\end{array}$} \\
\hline & No. & $(\%)$ & & $(\%)$ & & $(\%)$ & \\
\hline Agriculture, forestry and fishing & 7 & 1.79 & 1 & 0.33 & 8 & 1.15 & \\
\hline Mining and quarrying & 1 & 0.26 & - & - & 1 & 0.14 & \\
\hline Manufacturing* & 160 & 40.92 & 57 & 18.81 & 217 & 31.27 & \\
\hline $\begin{array}{l}\text { Manufacturing* } \\
\text { Electricity, gas, steam and air }\end{array}$ & 7 & 1.79 & 2 & 0.66 & 9 & 1.3 & 161 \\
\hline Construction & 7 & 1.79 & 18 & 5.94 & 25 & 3.6 & \\
\hline \multicolumn{8}{|l|}{ Wholesale and retail trade; repair of motor } \\
\hline Transportation and storage & 42 & 10.74 & 11 & 3.63 & 53 & 7.64 & \\
\hline \multicolumn{8}{|l|}{ Accommodation and food service } \\
\hline activities & 16 & 4.09 & 4 & 1.32 & 20 & 2.88 & \\
\hline Information and communication & 23 & 5.88 & 54 & 17.82 & 77 & 11.09 & \\
\hline Financial and insurance activities & 12 & 3.07 & 23 & 7.59 & 35 & 5.04 & \\
\hline Real estate activities & 1 & 0.26 & 2 & 0.66 & 3 & 0.43 & \\
\hline $\begin{array}{l}\text { Professional, scientific and technical } \\
\text { activities }\end{array}$ & 1 & 0.26 & & & 1 & 0.14 & \\
\hline \multicolumn{7}{|l|}{ Administrative and support service } & \\
\hline \multicolumn{7}{|l|}{ Public administration and defense; } & \\
\hline Education & 1 & 0.26 & 18 & 5.94 & 19 & 2.74 & \\
\hline Human health and social work activities & 8 & 2.05 & 25 & 8.25 & 33 & 4.76 & \\
\hline Arts, entertainment and recreation & 7 & 1.79 & 7 & 2.31 & 14 & 2.02 & \\
\hline Other service activities & 29 & 7.42 & 16 & 5.28 & 45 & 6.48 & \\
\hline N/a & 14 & 3.59 & 17 & 5.62 & 31 & 4.48 & Table 2. \\
\hline \multicolumn{7}{|c|}{$\begin{array}{l}\text { Note: *Mainly: automotive industry, manufacture of machinery and equipment, food products, chemicals, } \\
\text { furniture, wearing apparel, wood and products of wood and cork, fabricated metal products } \\
\text { Source: The authors' own study }\end{array}$} & $\begin{array}{l}\text { Structure of the } \\
\text { enterprises in terms } \\
\text { of the activity type }\end{array}$ \\
\hline
\end{tabular}

similar groups as far as their sizes (Table 1) and significant diversification in terms of their activity type (Table 2 ).

The primary statistical method was structural equation modeling (SEM). In addition, for the verification of the differences between the enterprises operating in different countries, Mann-Whitney U test statistics were calculated. All primary analyses were performed by mean of the PS IMAGIO software while multidimensional modeling was performed in AMOS 25.0.0.

\subsection{Measurement of organizational learning compatibility and the organizational learning processes}

It is widely accepted that OLC is a multidimensional construct (Jerez-Gómez et al., 2005; Chiva et al., 2007; Jerez-Gómez et al., 2019; Zgrzywa-Ziemak, 2019a), which can be assessed by examining the internal conditions and practices that facilitate OL (Jerez-Gómez et al., 2005; Migdadi, 2019; Zgrzywa-Ziemak, 2019a). There are only a few studies developing the measurement scale of learning capability (Jerez-Gómez et al., 2005; Chiva et al., 2007). These scales are accepted in the literature; however, they are very simplified and not all factors, the enablers of OL, are incorporated. In the paper, the OLC concept, which was developed and 


\begin{tabular}{|c|c|c|}
\hline Dimension & Definition & The theoretical basis \\
\hline $\begin{array}{l}\text { Individual as an } \\
\text { agent of OL }\end{array}$ & $\begin{array}{l}\text { Learning agents are involved in self-development and } \\
\text { undertake bottom-up initiatives to improve the } \\
\text { organization } \\
\text { The organization supports agents' efforts in terms of }\end{array}$ & $\begin{array}{l}\text { Individual as an agent of } \\
\text { ol (Friedman, } 2001) ; \\
\text { personal mastery (Senge, } \\
\text { 1990) }\end{array}$ \\
\hline
\end{tabular}

\section{2}

Collective learning

Inter-organizational learning

Information system mobilizing development

System thinking

Distributed leadership

Table 3.

Open organizational culture both individual development initiatives and organizational improvement

Collective learning requires intensive synergistic team-learning processes (of mutual knowledge verification and development) and synergistic collective-learning conditions (positive attitudes toward teamwork and relationships among employees oriented toward trust, openness, mutual respect, and cooperation)

Inter-organizational learning requires a broad network of differentiated inter-organizational relations; these relations have to be intense, oriented toward different modes of learning, open and characterized by partnership, not by domination

IS leads to the use of various methods of information transfer, their parallel use, the minimal standardization of communication methods and message forms. This is the vision referring to the concept of spontaneous communication, which implies the need to modify the knowledge about the different aspects of reality continuously and helps realize the wealth of perspectives and relativity of ratings. IS mobilizes for action, which may be implemented, inter alia through feedback systems, early warning systems, reporting focused on the development goals, high IS reliability

System thinking relates to coping with dynamic complexity. It requires the implementation of the practices and tools aimed at determining the systemic structures of organizational problems, identifying the interrelationships of decisions and actions in the short- and long-term perspective, locally and in the entire organization, the awareness of contribution to achieving organizational goals Distributed leadership means that power in the organization depends more on the ongoing tasks and conditions of their implementation than on the hierarchical position. It requires managerial support for lower-level initiatives, the readiness of employees to take over power and responsibility for their own actions and relationships between superiors and employees - open, based on trust and partnership, more casual, informal and dominated by mutual respect

Open culture means promoting and facilitating: the belief in the temporariness of knowledge (organizational reality and solutions must be
Teams as learners (Kasl et al., 1997); team learning (Senge, 1990); hallways (Dixon, 1997); social perspective (EasterbySmith and Araujo, 1999)

Absorptive capacity (Lane and Lubatkin, 1998); networks of learning (Powell et al., 1996); social capital (Inkpen and tsang, 2005)

The ol processes (Huber, 1991); the knowing-doing gap (Pfeffer and Sutton, 2000); knowledge conversion models (Nonaka and Takeuchi, 1995); is reliability

(Tworek et al., 2019)

Systems thinking (Senge, 1990)

Distributed leadership (Spillane, 2006; Bennett et al., 2003)

The concept of open and closed society by karl popper; closed-open

(continued) 


\begin{tabular}{|c|c|c|c|}
\hline \multirow[t]{2}{*}{ Dimension } & Definition & The theoretical basis & \multirow{2}{*}{ learning } \\
\hline & $\begin{array}{l}\text { continuously questioned), self-development, the } \\
\text { initiatives of continuous organizational } \\
\text { improvement, a sense of individual identity (which } \\
\text { does not mean the abandonment of teamwork but } \\
\text { expresses the cooperation of equal members of the } \\
\text { organization despite the diversity of interests and } \\
\text { views), openness to new ideas and risk-taking, errors } \\
\text { are treated as learning opportunities }\end{array}$ & $\begin{array}{l}\text { organizational culture } \\
\text { (Boerner and Gebert, } \\
\text { 2005); culture for learning } \\
\text { (Schein, 1992); mental } \\
\text { models (senge; 1990) }\end{array}$ & \\
\hline $\begin{array}{l}\text { Organic } \\
\text { organizational } \\
\text { structure }\end{array}$ & $\begin{array}{l}\text { The more conducive to learning the organizational } \\
\text { structure is, the smaller the limitations of the scope } \\
\text { of organizational behavior freedom are, which means } \\
\text { the low degree of standardization and formalization, } \\
\text { the domination of horizontal interactions in } \\
\text { communication, coordination, control and the } \\
\text { domination of the hierarchy of objectives over the } \\
\text { hierarchy of positions. Specialization and } \\
\text { centralization are not relevant }\end{array}$ & $\begin{array}{l}\text { Organic structure } \\
\text { (Martínez-León and } \\
\text { Martínez-García, 2011) }\end{array}$ & \\
\hline $\begin{array}{l}\text { 'Future-oriented' } \\
\text { strategy }\end{array}$ & $\begin{array}{l}\text { The strategy is focused on innovative solutions in } \\
\text { the industry and building new activities, is "stretch } \\
\text { and leverage" for the organization and not just } \\
\text { oriented toward the improvement of the current } \\
\text { activity. The strategy does not take the form of } \\
\text { detailed plans imposed from above. It begins to be a } \\
\text { learning process oriented toward seizing the } \\
\text { opportunity, in which the processes of its } \\
\text { formulation and implementation are open and new } \\
\text { opportunities are constantly tested, in which all the } \\
\text { participants are involved in the construction and } \\
\text { implementation of the strategy }\end{array}$ & $\begin{array}{l}\text { The resource-based view } \\
\text { (Prahalad and Hamel, } \\
\text { 1994); dynamic capabilities } \\
\text { (Helfat et al., 2007) }\end{array}$ & \\
\hline $\begin{array}{l}\text { Organizational } \\
\text { continuity }\end{array}$ & $\begin{array}{l}\text { The establishment of the core values is responsible } \\
\text { for maintaining a permanent identity in an } \\
\text { organization. The core values form the basis for } \\
\text { developing a shared vision }\end{array}$ & $\begin{array}{l}\text { Organizational continuity } \\
\text { (Kolb, 2003); core ideology } \\
\text { and envisioned future } \\
\text { (Collins and Porras, 2005); } \\
\text { shared vision (Senge, } \\
\text { 1990) }\end{array}$ & \\
\hline \multicolumn{2}{|c|}{ Source: Based on Zgrzywa-Ziemak (2019a) } & & \\
\hline
\end{tabular}

empirically verified by Zgrzywa-Ziemak (2019a), is adopted. Ten OLC dimensions measured by 124 items were identified. The OLC dimensions are defined in Table 3.

Firstly, the OLC scale measures practices and organizational conditions relating to the occurrence of the OL processes on different organizational and interorganizational levels. The following dimensions are present: individual as an agent of OL (eight items of the scale), collective learning (nine items), information system mobilizing development (ten items), system thinking (six items) and inter-OL (nine items).

Second, the OLC model integrates two - seemingly contradictory - perspectives: organizational volatility and continuity. The organizational volatility perspective refers to the vision of the organization that is extremely flexible (a chronically unfrozen system). The OLC dimensions responsible for the permanent change are distributed leadership (seven items), open organizational culture (nine items), organic organizational structure (four items) and "future-oriented" strategy (three items). 
JWL 33,3

However, the development of the organization requires a certain sense of the continuity of its existence: "the connectedness over time among organizational efforts and a sense or experience of ongoingness that links the past to the present and the present to future hopes and ideals" (Kolb, 2003, p. 180). One of the factors shaping OLC is organizational continuity (three items).

In this study, the original measurement - the OLC scale developed by Zgrzywa-Ziemak (2019a) was reduced to 68 items (out of 124). Each content-related aspect of the scale has been preserved with adherence to the constructs described in Table 1. Only the wording of some questions has been changed. For example, the question "How often do employees in your organization participate in the following forms of training and improvement of personnel?" in the original scale was evaluated by eight items relating to different formal forms of training while in our questionnaire there was one question: "To what extent does the following statement describe your company: Employees systematically participate in formally organized training." All items were rated on a five-point scale. The reliability of the constructs and scales was assessed using Cronbach's alpha and composite reliability (CR), indicating the adequate reliability of all constructs. Only the organic structure Cronbach's alpha is not greater than 0.70 (0.634), like in the original Zgrzywa-Ziemak's (2019a) model, but $\mathrm{CR}$ is 0.73 , which indicates the reliability of the construct. In checking the common method bias (CMB), Harman's single factor test was used, which revealed that CMB is not a significant issue in the study. Appendix 1 contains, among others, the descriptive statistics of all variables building the OLC scale. In Appendix 2, the results of the correlation analysis and reliability coefficients for all variables building the OLC scale are included. The confirmatory factor analysis was used to test the model (structural modeling was used in the subgroups for the Polish and Danish samples). The measures of the overall fit indicate the fit of the structural model: $X^{2}(70)=275.541, X^{2} / \mathrm{df}=3.936$, NFI $=0.950, \mathrm{CFI}=0.962$, RMSEA $=$ $0.065, \mathrm{SRMR}=0.018$. Although it would be interesting to compare our simplified measuring scale with the original one in a wider perspective, in view of the good matching of the OLC factor structure, we will focus on the purpose of the article.

The previously discussed the OLC concept includes five dimensions which are responsible for the practices and organizational conditions relating to the occurrence of the $O L$ processes: individual as an agent of OL, collective learning, information system mobilizing development, inter-OL and system thinking. Adapting these OLC dimensions to measure the OL processes will facilitate the real comparison of the models of the relationship between OLC and the OL processes and SP. The confirmatory factor analysis was used to test the OL processes model (structural modeling was used in the subgroups for the Polish and Danish samples). The measures of the overall fit indicate the fit of the structural model: $X^{2}(70)=46.317, X^{2} / \mathrm{df}=4.632, \mathrm{NFI}=0.979, \mathrm{CFI}=0.983, \mathrm{RMSEA}=0.072, \mathrm{SRMR}=0.011$. Harman's single factor test revealed that the CMB is not a significant issue in the study. Appendix 3 contains the results of the correlation analysis and reliability coefficients for all variables building the scale of OL processes.

\subsection{Measurement of sustainable performance}

There is still no single generally applicable definition used to disclose organizational performance regarding sustainable development. There are several initiatives related to the notion of sustainability reporting, including UNEP/Sustainability framework, GRI framework, the ACCA awards. There are also theoretical frameworks and business cases for measuring, managing and reporting environmental, social and economic impacts, including the sustainable balanced scorecard frameworks as a tool for evaluating and designing the objectives of BS (Figge et al., 2002; Milne and Gray, 2013; Hansen and Schaltegger, 2016). 
Most of the sustainability reporting and SP measurement scales are based on the organization's impact on social development, environmental protection and economic development. The basis for the formulation of the concept of SP was the analysis of the studies devoted to the theoretical foundations of measurement systems oriented toward sustainable development issues and those discussing the existing sustainability assessment methodologies (Singh et al., 2009; Chow and Chen, 2012; GRI, 2013; Maletic et al., 2015; Campos et al., 2015; Tworek et al., 2019).

$\mathrm{SP}$ is a multidimensional construct which combines economic, social and environmental

Organizational learning

performance. The measurement of economic performance also involved both financial and non-financial aspects and included five items. It assessed: revenues, productivity (low costs), quality (robustness, reliability, diligence), return on investment, the number of new products and/or services successfully implemented (Matić, 2012; Maletic et al., 2015). The social results were related to the extent to which organizations make a positive contribution to the creation of healthy and vibrant communities at the company and supply chain level (Vallance et al., 2011; Crane et al., 2014). The social results were measured by five items: employee satisfaction, health and safety at work, customer satisfaction, the organization's contribution to the development of healthy and life-friendly communities in general. The suppliers' compliance with social and environmental criteria was also assessed. The environmental results referred to the environmental impact of the organization's activities in terms of resources consumed and emissions and waste generated (Maletic et al., 2015; Campos et al., 2015). They were measured using five items and assessed: emissions, wastewater and waste, the consumption of hazardous, toxic, harmful materials, the consumption of total resources (materials, energy and water), the environmental impact of products or services sold and the impact on biodiversity. The respondents subjectively assessed the results compared to the competitive organizations on a five-point scale. In addition, one SP variable was created by averaging three variables relating to different groups of results (Tworek et al., 2019). The SP variable and the variables measuring each of the dimensions of SP should be considered reliable (Cronbach's alpha and CR exceeds 0.7). Appendix 1 contains descriptive statistics for all four SP variables. Appendixes 2 and 3 present the results of the correlation analysis and reliability coefficients.

\subsection{Study results}

Mann-Whitney U test was used to check whether the organizations from Poland and Denmark differ in terms of their learning ability and performance (Appendix 1). Danish organizations had significantly higher total OLC $(\phi<0.01)$, six out of ten factors had a significantly higher average: individual learning, collective learning, inter-OL, distributed leadership and "future-oriented" strategy $(\phi<0.01)$. The organizations operating in Denmark also achieved on average higher overall results than those operating in Poland $(\phi<0.05)$, but the significance of this difference was determined by significantly higher environmental performance $(\phi<0.01)$.

Two models were built to verify the research hypotheses: Model 1 refers to the relationship between OLC and SP, Model 2 reflects the relationship between the OL processes and SP. The SEM analysis was performed with the AMOS 25.0.0 statistical package. The maximum likelihood method was chosen. No post hoc modifications were conducted, because of good-fit indexes.

3.4.1 Model 1: organizational learning compatibility-sustainable performance. To analyze the relationship between OLC and SP, the SEM model - Model 1 - was developed (Figure 1). The measures of overall Model 1 fit indicate the fit of the structural model: $X^{2}$ $(88)=307.248, X^{2} / \mathrm{df}=3.491, \mathrm{NFI}=0.948, \mathrm{CFI}=0.962, \mathrm{RMSEA}=0.060, \mathrm{SRMR}=0.017$. All 
JWL
33,3

166

Figure 1.

Model 1: a structural model of the OLC and SP relationship (Poland $n=391$; Denmark $n=303$ )

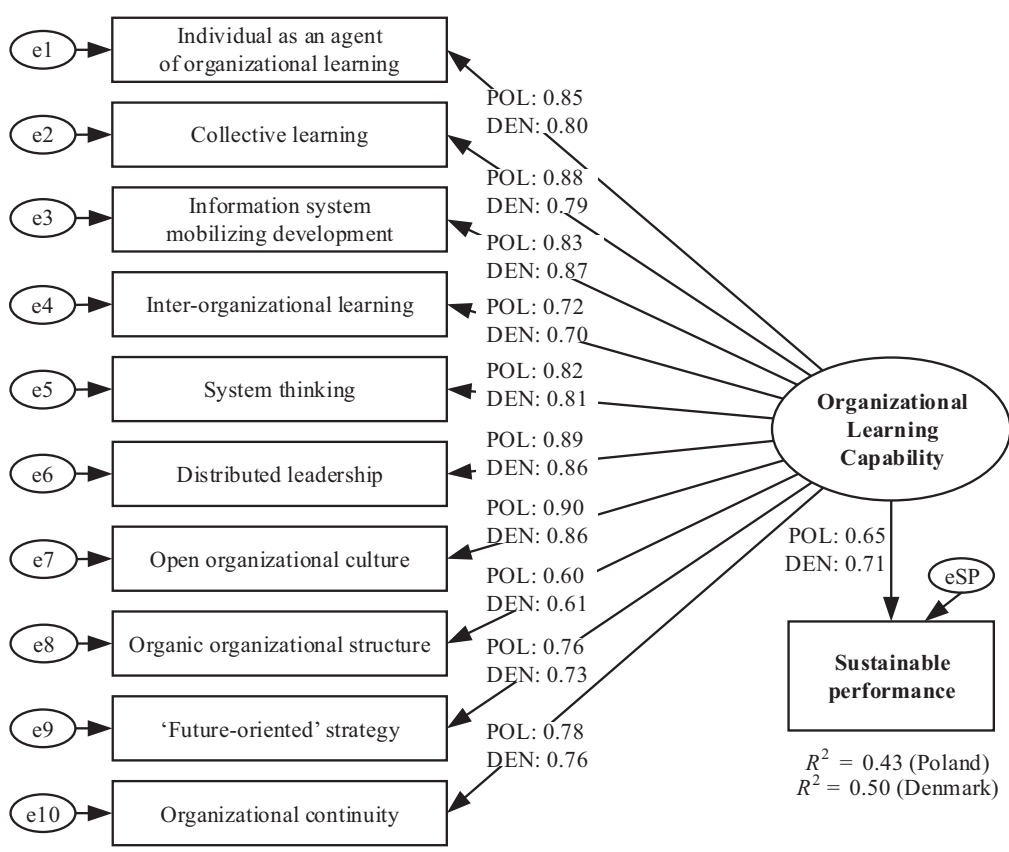

Notes: POL - standardized regression weights for Poland; DEN - standardized regression weights for Denmark

estimated parameters are significant $(p<0.001)$. The figure shows standardized regression weights for both countries.

Structural modeling was applied in the subgroups: it was assumed that the form of the model is the same for Denmark and Poland; there are only differences in the values of estimated parameters. The analysis of the matrix of the values of the statistical significance tests of parameter differences (pairwise parameter comparisons) proves that the estimates of most parameters of the model for the two groups are statistically significantly different (no differences were recorded only for the following dimensions: collective learning, system thinking and distributed leadership). This means that the share of individual factors in the OLC structure for each country is different. This is a potentially interesting direction for future research.

The relationship between OLC and SP proved to be statistically significant for both countries - regression weight for Denmark is $0.71(p<0.001)$, whereas for Poland, it is 0.65 $(p<0.001)$, with the effect being higher for Denmark and the difference being statistically significant. As a result, there are no grounds to reject the $H 1$ hypothesis.

The influence of OLC on particular groups of organizational results (economic, social and environmental) was additionally examined. The models which are analogous to Model 1 were built. Only the result variable was changed and thus the following successive models were formulated: Model 1_ECO, Model_1_SOC and Model 1_ENV. Table 4 presents the characteristics of individual models and the output model for the OLC-SP relationship. 


\begin{tabular}{|c|c|c|c|c|c|c|c|}
\hline \multirow[b]{2}{*}{ Model } & & & & \multicolumn{2}{|c|}{$\begin{array}{c}\text { Standardized regression } \\
\text { weights }\end{array}$} & \multirow[t]{2}{*}{ Measures of overall model fit } & \multirow{2}{*}{$\begin{array}{r}\text { Organizational } \\
\text { learning }\end{array}$} \\
\hline & & & & $\begin{array}{l}\text { Poland } \\
(n=391)\end{array}$ & $\begin{array}{l}\text { Denmark } \\
(n=303)\end{array}$ & & \\
\hline Model 1 & OLC & & $\mathrm{SP}$ & 0.65 & 0.71 & \multirow{5}{*}{$\begin{array}{l}X^{2}(88)=307.248, X^{2} / \mathrm{df}=3.491, \\
\mathrm{NFI}=0.94, \mathrm{CFI}=0.962, \\
\mathrm{RMSEA}=0.060, \mathrm{SRMR}=0.017 \\
X^{2}(88)=312.147, X^{2} / \mathrm{df}=3.547, \\
\mathrm{NFI}=0.946, \mathrm{CFI}=0.961, \\
\mathrm{RMSEA}=0.061, \mathrm{SRMR}=0.017 \\
X^{2}(88)=307,747, X^{2} / \mathrm{df}=3.497, \\
\mathrm{NFI}=0.948, \mathrm{CFI}=0.962, \\
\mathrm{RMSEA}=0.060, \mathrm{SRMR}=0.017 \\
X^{2}(88)=306,479, X^{2} / \mathrm{df}=3.483, \\
\mathrm{NFI}=0.946, \mathrm{CFI}=0.961, \\
\text { RMSEA }=0.060, \mathrm{SRMR}=0.017\end{array}$} & 167 \\
\hline Model 1_ECO & OLC & $\rightarrow$ & $\begin{array}{l}\text { Economic } \\
\text { performance }\end{array}$ & 0.55 & 0.57 & & \\
\hline Model 1_SOC & OLC & $\rightarrow$ & $\begin{array}{l}\text { Social } \\
\text { performance }\end{array}$ & 0.64 & 0.66 & & $\begin{array}{r}\text { Table } 4 . \\
\text { Comparison of the }\end{array}$ \\
\hline Model 1_ENV & OLC & $\rightarrow$ & $\begin{array}{l}\text { Environmental } \\
\text { performance }\end{array}$ & 0.41 & 0.57 & & $\begin{array}{r}\text { relationships } \\
\text { between OLC and SP } \\
\text { and the SP }\end{array}$ \\
\hline \multicolumn{6}{|c|}{ Note: All estimated parameters are significant $(\phi<0.01)$} & & dimensions \\
\hline
\end{tabular}

All models are well fitted to the data. The regression weights of result variables in both countries allow assuming that the OLC effect on performance for integrated economic, social and environmental results, i.e. SP, is more significant than for any group of results. In both countries, OLC has the highest impact, following the integrated results, on social performance (in organizations operating in Poland, it is similar to the impact on the overall results). Moreover, the impact of OLC on environmental performance in Poland is low.

3.4.2 Model 2: organizational learning processes-sustainable performance. To verify the relationship between the OL processes and SP, a SEM model was built: Model 2 (Figure 2). The measures of overall fit indicate the fit of the structural model: X2(18) =55,235, X2/df = $3.069, \mathrm{NFI}=0.979, \mathrm{CFI}=0.986, \mathrm{RMSEA}=0.055, \mathrm{SRMR}=0.010$. All estimated parameters

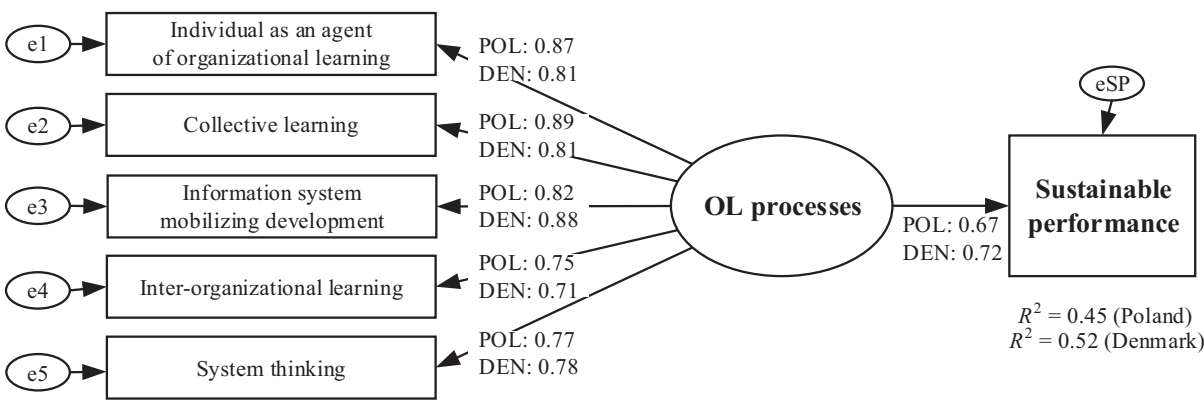

Notes: POL - standardized regression weights for Poland; DEN - standardized regression weights for Denmark
Figure 2.

Model 2: a structural model of the OL processes and SP relation (Poland $n=$ 391; Denmark $n=$ 
JWL 33,3

168

are significant $(\phi<0.001)$. The standardized regression weights for Poland and Denmark are shown in Figure 2.

Structural modeling in the subgroups for the organizations in Poland and Denmark was used once more. In the case of this model, the analysis of the matrix of the values of the statistical significance tests of parameter differences showed that there are no significant differences in the estimates of most parameters. Only the parameters of the information system mobilizing the development differ significantly. The effect of the OL processes on SP is lower in Poland than in Denmark and this difference is statistically significant. The relationship between the OL processes and SP has been statistically significant and positive for both countries; regression weights for Denmark are $0.72(p<0.001)$ and for Poland are $0.67(p<0.001)$. As a result, there are no grounds to reject the $H 2$ hypothesis.

Likewise, in the case of examining the relationship between the OL processes and organizational performance, these processes have a more significant impact on the integrated results of SP than on the individual groups of results (Table 5).

The model of the relationship between the OL processes and SP (Model 2) is slightly better suited to the data than the model of the relationship between OLC and SP (Model 1). Moreover, in Model 2, the regression weights for SP for both countries are higher than in Model 1. It should be additionally emphasized that a number of additional statistical analyses were carried out for this article. A significant result is that the removal of any variable or variables from Model 2 resulted in the worsening of the fit of the models (the fit measures were worse than for Models 1 and 2). Model 2 should, therefore, be considered the simplest and best fit model. The $H 3$ hypothesis should be rejected. The effect of OLC on SP is not higher than the effect of the OL processes on SP.

\section{Conclusions}

\subsection{Theoretical implications}

The empirical studies confirm the positive relationship between OL and organizational performance. Referring to the meta-analysis of the works in the field (Goh et al., 2012; Zgrzywa-Ziemak, 2015; Watkins and Kim, 2018), it should be stressed that the results

Table 5.

Comparison of the models of the relationships between the OL processes and SP and the SP dimensions

\begin{tabular}{|c|c|c|c|c|c|}
\hline Model & & & \multicolumn{2}{|c|}{$\begin{array}{l}\text { Standardized } \\
\text { regression weights }\end{array}$} & $\begin{array}{l}\text { Measures of overall } \\
\text { model fit }\end{array}$ \\
\hline Model 2 & $\begin{array}{l}\text { OLC } \\
\text { processes }\end{array}$ & $\rightarrow \mathrm{SP}$ & 0.67 & 0.720 & $\begin{array}{l}X^{2}(18)=55,235, X^{2} / \mathrm{df}=3.069 \\
\mathrm{NFI}=0.979, \mathrm{CFI}=0.986 \\
\text { RMSEA }=0.055, \text { SRMR }=0.010\end{array}$ \\
\hline Model 2_ECO & $\begin{array}{l}\text { OLC } \\
\text { processes }\end{array}$ & $\rightarrow \begin{array}{l}\text { Economic } \\
\text { performance }\end{array}$ & 0.58 & 0.58 & $\begin{array}{l}X^{2}(18)=53,524, X^{2} / \mathrm{df}=2.974 \\
\mathrm{NFI}=0.978, \mathrm{CFI}=0.985 \\
\mathrm{RMSEA}=0.053, \mathrm{SRMR}=0.010\end{array}$ \\
\hline Model 2_SOC & $\begin{array}{l}\text { OLC } \\
\text { processes }\end{array}$ & $\rightarrow \begin{array}{l}\text { Social } \\
\text { performance }\end{array}$ & 0.67 & 0.68 & $\begin{array}{l}X^{2}(18)=57,673, X^{2} / \mathrm{df}=3.327 \\
\mathrm{NFI}=0.978, \mathrm{CFI}=0.984 \\
\mathrm{RMSEA}=0.056, \text { SRMR }=0.010\end{array}$ \\
\hline Model 2_ENV & $\begin{array}{l}\text { OLC } \\
\text { processes }\end{array}$ & $\rightarrow \begin{array}{l}\text { Environmental } \\
\text { performance }\end{array}$ & 0.41 & 0.57 & $\begin{array}{l}X^{2}(18)=58,359, X^{2} / \mathrm{df}=3.242 \\
\mathrm{NFI}=0.976, \mathrm{CFI}=0.983 \\
\text { RMSEA }=0.057, \text { SRMR }=0.011\end{array}$ \\
\hline
\end{tabular}

Note: All estimated parameters are significant $(p<0.01)$ 
obtained are in line with the dominant trend of the previous empirical studies. However, they are a significant extension of the previous studies. First of all, the link between OL and integrated organizational performance has proved to be the strongest. It was stronger than the relationship between OL and any type of organizational performance: economic, social or environmental. OL can, therefore, be assumed to promote the synergy of the organization's results.

Second, owing to the nature of the specified components of organizational performance, referring to the basic dimensions of sustainable development, the research proves that the relationship between OL and SP is positive and statistically significant. Thus, the results obtained constitute an essential voice in the discussion on the importance of OL for BS.

Thirdly, two constructs relating to OL are covered in the study: OLC and the OL processes. The second construct (the OL processes) was part of the first construct (OLC), which enabled the comparison of the models of relationships between the listed constructs and SP. For both models, OLC-SP (Model 1) and the OL processes-SP (Model 2), the relationships proved to be statistically significant and positive. Both measures of the quality of both models as well as the strength of the relationship between the SP and the constructs measuring OL were the best for Model 2: the OL processes-SP. As a result, the research conducted supports the view that the intensification of the OL processes is crucial for BS. The organization committed to sustainable development has to redesign itself radically and continuously review the adopted strategies, products, processes, technologies, measurement systems, the ways of communication and cooperation with the environment in the context of sustainability.

It was, therefore, necessary to depart from the assumption that the OLC concept would be more significant for BS than merely the OL processes. OLC meets the concept of "metalearning" and it takes into account not only the factors which are a manifestation of the OL processes but also the factors responsible for ongoing volatility and ensuring organizational continuity. Based on the guidance of researchers, particular importance has been attached to organizational continuity that integrates organizational values and a shared vision (Senge et al., 2010; Molnar and Mulvihill, 2003; Zgrzywa-Ziemak, 2019a). However, in the OLC concept model devised by Zgrzywa-Ziemak (2019a), in no way does the organizational continuity factor determine the content of values or vision. Therefore, for future research, it would be interesting to include the moderators relating to the context of sustainability in the model of the relationship between OL processes and BS. With regard to the concept of organizational continuity, the moderating variables could refer to: the intensity of holisticaltruistic values in the organization [in relation to the holistic-altruistic axiology of sustainable development developed by Papuziński (2013)] or the degree of commitment to address the development of society and a positive impact on the restoration of the environment embodied in the highest-level organizational goals [in relation to Senge et al. (2010)].

Fourth, it should be mentioned that this study adopts Zgrzywa-Ziemak's concept of OL processes-shaping factors (2019a). A factor that goes beyond most of the concepts of the OL processes is system thinking practices. According to the holistic approach to BS, the key is to accurately perceive, understand and respond to interdependent economic, social and environmental problems - multi-faceted nonlinear fluid and unpredictably complex, often contradictory, and time-variable problems (Hahn et al., 2015). This requires a move away from traditional, mechanistic, deterministic thinking toward integrated cognitive logic (Gao and Bansal, 2013; Zgrzywa-Ziemak, 2019b). The integrated cognitive logic as the BS dimension entails understanding the dynamic structure of interdependencies within an organization and the organization in its environment, the interdependencies among entities, 
JWL 33,3

resources, events and outcomes relating to the economic, social and environmental dimensions, in the short, long and intergenerational time horizons, locally and globally (Zgrzywa-Ziemak, 2019b). This integrated cognitive logic is precisely system thinking in the sense of Senge (1990). In the OL processes-SP relationship model, system thinking, although not one of the most important factors, is statistically significant. The OL processes model of four factors (without system thinking) proved to be inferior owing to the adopted measures of the fit and strength of the relationship between learning and SP to Model 2 (as well as to Model 1).

Finally, the studies show that the link between OL and SP was higher in Denmark than in Poland. In view of the analyses carried out, it can be assumed that this state of affairs is mainly owing to the statistically significantly lower involvement of Polish organizations in actions for the natural environment. However, it can be noted that the OLC model for the Danish sample differs from the Polish one by the presence of only one factor - IS mobilizing development. It is the factor that not only measures the intensity and freedom of acquiring, distributing, interpreting and memorizing information but, with reference to the work of Pfeffer and Sutton (2000), it also includes the mechanisms focused on the use of information in the activities aimed at achieving specific results (like feedback systems, early warning systems, reporting focused on the development goals, high IS reliability). It was considered relevant and interesting to highlight this difference. The questions arise as to whether it is a result of cultural differences or maybe of technological advancement. The answer could be provided in the course of the studies carried out in other cultural contexts.

\subsection{Implications for practice}

Managers regard the challenges of sustainable development as the decisive forces affecting the ways of thinking, acting, managing and competing in the short and long-term perspectives (Berns et al., 2009). Sustainable development issues not only have a direct impact on companies' operations but they are also intensified as a result of stakeholders' pressure on the environmental impact of companies and people's quality of life in general and as a response to the strategies adopted by competitors (Rosati and Faria, 2019). The business's commitment to sustainable development is reflected, among other things, in its economic, environmental and social performance.

In the light of this research, it can be said that the intensification of the OL processes is essential not only for achieving higher results but also for the integration of very mixed results, including economic, social and environmental aspects. Although OL is - to a large extent - spontaneous, it is possible to indicate such conditions that will allow accelerating and directing learning processes. From a practical standpoint, managers must create the conditions for intensifying the OL processes in favor of SP.

Managers should, therefore, support the continuous development of employees' skills and qualifications as well as their initiatives to improve the business's processes and products (factor: individual as an agent of OL). Among other things, the processes of personnel selection and development, formal training and the creation of learning conditions in daily work, as well as the motivation and provision of (both temporary and material) resources for the development of individuals and their involvement in the improvement of the organization are vital here.

Second, managers must encourage the intensification of synergic collective learning processes, as a result of which the members of the organization jointly verify and create new knowledge (factor: collective learning). It is essential to organize work and provide resources for sub-processes such as: integrating divergent perspectives, experimenting together, searching for information beyond the boundaries of organizational units and sharing 
knowledge with others in the company. Appropriate work organization can include the promotion of flexible, formal and informal forms of teamwork. Teamwork must be valued in the organization not only as an efficient and effective mechanism for effectively carrying out complex tasks but also as a way of acting that can lead to breakthrough thinking. It is necessary to develop the ability to learn together and to foster the formation of relationships between employees focused on commitment, trust, openness, mutual respect and cooperation.

Third, information systems in the organization must achieve two goals (factor:

Organizational learning information system mobilizing development). On the one hand, they must enable an intensive and free flow of information within the organization as well as between the organization and its environment. It is possible by using different ways of transferring information, encouraging their parallel use, performing the minimum standardization of communication methods or forms of messages and actions for IS reliability. On the other hand, formal information systems must be shaped in such a way as to mobilize the organization's members. As mentioned previously, it can be facilitated by feedback, early warning or reporting systems.

Fourth, the OL processes require the organization to develop a wide network of interorganizational contacts (with customers, business partners, business environment organizations), including both formal and informal relationships resulting from the involvement of all employees in their building (factor: inter-OL). Interorganizational relationships must, among other things, be oriented toward finding and acquiring new knowledge for the organization, learning from external partners and developing new knowledge with them - technology and/or products (so as to share risks, costs and/or pool competences). The relationship must be a partnership. It cannot be based on domination or compulsion.

Finally, managers should encourage system thinking practices, i.e. behaviors for dealing with dynamic complexity in the organization (factor: system thinking). Primarily, it involves the implementation of practices that are aimed at a thorough analysis of the consequences of decisions (in the short and long term, locally and throughout the enterprise), that are oriented toward determining the system structures of organizational problems (for example, by using modeling and simulation tools in the process of organizational problem solving and decision-making) and a multidimensional evaluation of the quality of the decisions made. System thinking also requires developing a sense of responsibility for the organization's global performance among all employees and ensuring that middle and top managers do not achieve their results at the expense of other parts of the organization.

This study shows that the intensification of the OL processes favors SP. However, the OL processes can be not only intensified but also targeted. The results of the research do not refer to the importance of the content of the organizational objectives, values or measures of the relationship between the OL processes and the organization. However, it seems justified to conclude that critical managerial decisions should guide the OL processes. Thus, they should pertain to the implementing holistic-altruistic core values, shaping objectives and measures related to sustainable development issues.

\subsection{Limitations and future research directions}

It is essential to underline that the research presented above has some limitations. First of all, the research sample was not representative. However, this was owing to the conscious assumptions as it was assumed that it was crucial to obtain a sample of organizations with the characteristics which would allow a full understanding of the nature of the relationship under consideration. Therefore, efforts were made to ensure that the number of groups of the 
organizations of different sizes was similar for both countries. Second, model verification is based only on two samples - organizations operating in Poland and Denmark. The hypothesis requires further verification in different business contexts. Additionally, there are undoubtedly different factors influencing BS (not only OL), which have not been included in this empirical research. It would be, therefore, advisable to consider in the future the impact of the OL processes on SP, taking into account other (internal and external) factors which, as emerges from the literature review, have an impact on organizational performance on the one hand and on BS, on the other. Furthermore, the relationship tested in this study represents a snapshot in time. For this reason, further research could attempt to test continuity to see changes in OLC, BS and OP. Moreover, it would be interesting to verify the presence of the variables moderating the relationship between the OL processes and SP. In addition, the conclusion referring to the differences between countries (cultural or technological advancement and resources) is undoubtedly an attention-grabbing direction for future research. Finally, it would be essential to relate the OL processes to BS understood from the process perspective and not from the organizational performance perspective.

\section{References}

Alegre, J. and Chiva, R. (2008), "Assessing the impact of organizational learning capability on product innovation performance: an empirical test”, Technovation, Vol. 28 No. 6, pp. 315-326, doi: 10.1016/j.technovation.2007.09.003.

Alegre, J. and Chiva, R. (2013), "Linking entrepreneurial orientation and firm performance: the role of organizational learning capability and innovation performance", Journal of Small Business Management, Vol. 51 No. 4, pp. 491-507, doi: 10.1111/jsbm.12005.

Arend, R. and Bromiley, P. (2009), “Assessing the dynamic capabilities view: spare change, everyone?”, Strategic Organization, Vol. 7 No. 1, pp. 75-90, doi: 10.1177/1476127008100132.

Baker, W.E. and Sinkula, J.M. (1999), "Learning orientation, market orientation, and innovation: integrating and extending models of organizational performance", Journal of Market-Focused Management, Vol. 4 No. 4, pp. 295-308, doi: 10.1023/A:1009830402395.

Bennett, N., Wise, C., Woods, P.A. and Harvey, J.A. (2003), Distributed Leadership: Full Report, National College for School Leadership, Nottingham.

Berns, M., Townend, A., Khayat, Z., Balagopal, B., Reeves, M., Hopkins, M.S. and Kruschwitz, N. (2009), "The business of sustainability: what it means to managers now", MIT Sloan Management Review, Vol. 51 No. 1, pp. 20-26.

Bhatnagar, J. (2006), "Measuring organizational learning capability in Indian managers and establishing firm performance linkage”, The Learning Organization, Vol. 13 No. 5, pp. 416-433, doi: 10.1108/09696470610679965.

Boerner, S. and Gebert, D. (2005), "Organizational culture and creative processes comparing German theater companies and scientific institutes", Nonprofit Management and Leadership, Vol. 16 No. 2, pp. 209-220, doi: 10.1002/nml.10.

Campos, L.M.S., De Melo Heizen, D.A., Verdinelli, M.A. and Cauchick Miguel, P.A. (2015), "Environmental performance indicators: a study on ISO 14001 certified companies", Journal of Cleaner Production, Vol. 99, pp. 286-296, doi: 10.1016/j.jclepro.2015.03.019.

Chiva, R., Alegre, J. and Lapiedra, R. (2007), "Measuring organisational learning capability among the workforce", International Journal of Manpower, Vol. 28 Nos 3/4, pp. 224-242, doi: 10.1108/ 01437720710755227.

Chow, W.S. and Chen, Y. (2012), "Corporate sustainable development: testing a new scale based on the mainland Chinese context”, Journal of Business Ethics, Vol. 105 No. 4, pp. 519-533, doi: 10.1007/ s10551-011-0983-x. 
Collins, J.C. and Porras, J.I. (2005), Built to Last: Successful Habits of Visionary Companies, Random House.

Cook, S.D. and Yanow, D. (1993), "Culture and organizational learning", Journal of Management Inquiry, Vol. 2 No. 4, pp. 373-390, doi: 10.1177/105649269324010.

Crane, A., Palazzo, G., Spence, L.J. and Matten, D. (2014), “Contesting the value of 'creating shared value”, California Management Review, Vol. 56 No. 2, pp. 130-153, doi: 10.1525/cmr.2014.56.2.130.

Crossan, M.M., Lane, H.W. and White, R.E. (1999), "An organizational learning framework: from intuition to institution", Academy of Management Review, Vol. 24 No. 3, pp. 522-537, doi: 10.5465/amr.1999.2202135.

De Holan, P.M. and Phillips, N. (2011), "Organizational forgetting. Handbook of organizational learning and knowledge management", in Easterby-Smith, M., Burgoyne, J. and Araujo, L. (Eds), Organizational Learning and the Learning Organization. Developments in Theory and Practice, SAGE, London, pp. 433-451, doi: 10.1002/9781119207245.ch20.

Dibella, A.J., Nevis, E.C. and Gould, J.M. (1996), "Understanding organizational learning capability", Journal of Management Studies, Vol. 33 No. 3, pp. 361-379, doi: 10.1111/j.14676486.1996.tb00806.x.

Dixon, N.M. (1997), "The hallways of learning”, Organizational Dynamics, Spring, Vol. 25 No. 4, pp. 23-33, doi: 10.1016/S0090-2616(97)90034-6..

Dodgson, M. (1993), "Organizational learning: a review of some literatures”, Organization Studies, Vol. 14 No. 3, pp. 375-394, doi: 10.1016/S0090-2616(97)90034-6.

Dyllick, T. and Muff, K. (2016), "Clarifying the meaning of sustainable business: introducing a typology from business-as-usual to true business sustainability", Organization and Environment, Vol. 29 No. 2, pp. 156-174, doi: 10.1177/1086026615575176.

Easterby-Smith, M. and Araujo, L. (1999), "Organizational learning: current debates and opportunities”, in Easterby-Smith, M., Burgoyne, J. and Araujo, L. (Eds), Organizational Learning and the Learning Organization. Developments in Theory and Practice, SAGE, London, pp. 1-21, doi: 10.4135/9781446218297.n1.

Easterby-Smith, M. and Lyles, M.A. (2011), Handbook of Organizational Learning and Knowledge Management, John Wiley and Sons, doi: 10.1002/9781119207245.

Edwards, M.G. (2009), "An integrative metatheory for organisational learning and sustainability in turbulent times", The Learning Organization, Vol. 16 No. 3, pp. 189-207, doi: 10.1108/ 09696470910949926.

Figge, F., Hahn, T., Schaltegger, S. and Wagner, M. (2002), "The sustainability balanced scorecardlinking sustainability management to business strategy", Business Strategy and the Environment, Vol. 11 No. 5, pp. 269-284, doi: 10.1002/bse.339.

Friedman, V.J. (2001), "The individual as agent of organizational learning”, in Dierkes, M., Berthoin Antal, A., Child, J. and Nonaka, I. (Eds), Handbook of Organizational Learning and Knowledge, University Press, Oxford New York, NY, pp. 398-414.

Gao, J. and Bansal, P. (2013), "Instrumental and integrative logics in business sustainability", Journal of Business Ethics, Vol. 112 No. 2, pp. 241-255, doi: 10.1007/s10551-012-1245-2.

Goh, S.C. (2003), "Improving organizational learning capability: lessons from two case studies", The Learning Organization, Vol. 10 No. 4, pp. 216-227, doi: 10.1108/09696470310476981.

Goh, S.C., Elliott, C. and Quon, T. (2012), "The relationship between learning capability and organizational performance. Meta-analytic examination”, The Learning Organization, Vol. 19 No. 2, pp. 92-108, doi: 10.1108/09696471211201461.

GRI (2013), "Sustainability reporting guidelines (G4)”, Global Reporting Initiative.

Hahn, T., Pinkse, J., Preuss, L. and Figge, F. (2015), "Tensions in business sustainability: toward an integrative framework", Journal of Business Ethics, Vol. 127 No. 2, pp. 297-316, doi: 10.1007/ s10551-014-2047-5. 
JWL 33,3

Hansen, E.G. and Schaltegger, S. (2016), "The sustainability balanced scorecard: a systematic review of architectures", Journal of Business Ethics, Vol. 133 No. 2, pp. 193-221, doi: 10.1007/s10551-0142340-3.

Hart, S.L. and Milstein, M.B. (2003), "Creating sustainable value", Academy of Management Perspectives, Vol. 17 No. 2, pp. 56-67, doi: 10.5465/ame.2003.10025194.

Helfat, C.E., Finkelstein, S., Mitchell, W., Peteraf, M., Singh, H., Teece, D. and Winter, S.G. (2007), Dynamic Capabilities: Understanding Strategic Change in Organizations, John Wiley and Sons.

Huber, G.P. (1991), "Organizational learning: the contributing processes and the literatures", Organization Science, Vol. 2 No. 1, pp. 88-115, doi: 10.1287/orsc.2.1.88.

Ihlen, Ø. (2015), "It is five minutes to midnight and all is quiet': corporate rhetoric and sustainability", Management Communication Quarterly, Vol. 29 No. 1, pp. 145-152, doi: 10.1177/ 0893318914563145 .

Inkpen, A.C. and Tsang, E.W.K. (2005), "Social capital, networks, and knowledge transfer", Academy of Management Review, Vol. 30 No. 1, pp. 146-165, doi: 10.5465/amr.2005.15281445.

Jerez-Gómez, P., Céspedes-Lorente, J. and Pérez-Valls, M. (2019), “Do high-performance human resource practices work? The mediating role of organizational learning capability", Journal of Management and Organization, Vol. 25 No. 2, pp. 189-210, doi: 10.1017/jmo.2017.55.

Jerez-Gómez, P., Cespedes-Lorente, J. and Valle-Cabera, R. (2005), “Organizational learning capability: a proposal of measurement”, Journal of Business Research, Vol. 58 No. 6, pp. 715-725, doi: 10.1016/ j.jbusres.2003.11.002.

Jiménez-Jiménez, D. and Sanz-Valle, R. (2011), "Innovation, organizational learning, and performance”, Journal of Business Research, Vol. 64 No. 4, pp. 408-417, doi: 10.1016/j.jbusres.2010.09.010.

Kasl, E., Marsick, V.J. and Dechant, K. (1997), "Teams as learners. A research-based model of team learning", The Journal of Applied Behavioral Science, Vol. 33 No. 2, pp. 227-246, doi: 10.1177/ 0021886397332010.

Kim, D.H. and Senge, P.M. (1994), "Putting systems thinking into practice", System Dynamics Review, Vol. 10 Nos 2/3, pp. 277-290, doi: 10.1002/sdr.4260100213.

Kolb, D.G. (2003), "Seeking continuity amidst organizational change. A storytelling approach", Journal of Management Inquiry, Vol. 12 No. 2, pp. 180-183, doi: 10.1177/1056492603012002010.

Lane, P.J. and Lubatkin, M. (1998), "Relative absorptive capacity and interorganizational learning", Strategic Management Journal, Vol. 19 No. 5, pp. 461-477, doi: 10.1002/(SICI)1097-0266(199805) 19:5<461::AID-SMJ953>3.0.CO;2-L.

Maletic, M., Maletic, D., Dahlgaard, J., Dahlgaard-Park, S.M. and Gomišcek, B. (2015), "Do corporate sustainability practices enhance organizational economic performance?", International Journal of Quality and Service Sciences, Vol. 7 Nos 2/3, pp. 184-200, doi: 10.1108/IJQSS-02-2015-0025.

Marsick, V.J. and Watkins, K.E. (1999), Facilitating Learning Organizations: Making Learning Count, Gower Publishing.

Martínez-León, I.M. and Martínez-García, J.A. (2011), "The influence of organizational structure on organizational learning", International Journal of Manpower, Vol. 32 Nos 5/6, pp. 537-566, doi: $10.1108 / 01437721111158198$.

Matić, I. (2012), "Measuring the effects of learning on business performances: proposed performance measurement model", The Journal of American Academy of Business, Vol. 18 No. 1, pp. 278-284.

Migdadi, M. (2019), "Organizational learning capability, innovation and organizational performance", European Journal of Innovation Management, doi: 10.1108/EJIM-11-2018-0246.

Milne, M.J. and Gray, R. (2013), "W(h)ither ecology? The triple bottom line, the global reporting initiative, and corporate sustainability reporting”, Journal of Business Ethics, Vol. 118 No. 1, pp. 13-29, doi: 10.1007/s10551-012-1543-8. 
Molnar, E. and Mulvihill, P.R. (2003), "Sustainability-focused organizational learning: recent experiences and new challenges", Journal of Environmental Planning and Management, Vol. 46 No. 2, pp. 167-176, doi: 10.1080/0964056032000070990.

Nonaka, I. and Takeuchi, H. (1995), The Knowledge - Creating Company, Oxford University Press, New York, NY.

Papuziński, A. (2013), "The axiology of sustainable development: an attempt at typologization", Problems of Sustainable Development, Vol. 8, pp. 5-25.

Parrish, B.D. (2007), "Designing the sustainable enterprise”, Futures, Vol. 39 No. 7, pp. 846-860, doi: 10.1016/j.futures.2006.12.007.

Perez Lopez, S., Peon, J.M. and Ordas, C.M. (2005), "Organizational learning as a determining factor in business performance”, The Learning Organization, Vol. 12 No. 3, pp. 227-245, doi: 10.1108/09696470510592494.

Pesämaa, O., Shoham, A., Wincent, J. and Ruvio, A.A. (2013), "How a learning orientation affects drivers of innovativeness and performance in service delivery", Journal of Engineering and Technology Management, Vol. 30 No. 2, pp. 169-187, doi: 10.1016/j.jengtecman.2013.01.004.

Pfeffer, J. and Sutton, R.I. (2000), The Knowing-Doing Gap: How Smart Companies Turn Knowledge into Action, Harvard Business Press.

Porter, M.E. and Kramer, M.R. (2011), “Creating shared value”, HBR, Vol. 8, pp. 62-77.

Powell, W.W., Koput, K.W. and Smith-Doerr, L. (1996), "Interorganizational collaboration and the locus of innovation: networks of learning in biotechnology", Administrative Science Quarterly, Vol. 41 No. 1, pp. 116-145, doi: 10.2307/2393988.

Prahalad, C.K and Hamel, G. (1994), Competing for the Future, Harvard Business School Press, Boston.

Prieto, I. and Revilla, E. (2006), "Learning capability and business performance: a non-financial and financial assessment”, The Learning Organization, Vol. 13 No. 2, pp. 166-185, doi: 10.1108/ 09696470610645494.

RobecoSAM (2015), available at: www.sustainability-indices.com/sustainability-assessment/ index.jsp

Rosati, F. and Faria, L.G.D. (2019), "Business contribution to the sustainable development agenda: organizational factors related to early adoption of SDG reporting", Corporate Social Responsibility and Environmental Management, Vol. 26 No. 3, pp. 588-597, doi: 10.1002/csr.1705.

Salzmann, O., Ionescu-Somers, A. and Steger, U. (2005), "The business case for corporate sustainability: literature review and research options", European Management Journal, Vol. 23 No. 1, pp. 27-36, doi: 10.1016/j.emj.2004.12.007.

Schein, E.H. (1992), Organizational Culture and Leadership, Jossey-Bass Publishers, San Francisco, CA.

Schön, D. and Argyris, C. (1996), Organizational Learning II: Theory, Method and Practice, AddisonWesley Publishing Company, MA.

Sekerka, L.E. and Stimel, D. (2011), "How durable is sustainable enterprise? Ecological sustainability meets the reality of tough economic times", Business Horizons, Vol. 54 No. 2, pp. 115-124, doi: 10.1016/j.bushor.2010.09.006.

Senge, P. (1990), The Fifth Discipline: The Art and Science of the Learning Organization, Currency Doubleday, New York, NY.

Senge, P., Smith, B., Kruschwitz, N., Laur, J. and Schley, S. (2010), The Necessary Revolution: How Individuals and Organisations Are Working Together to Create a Sustainable World, Nicholas Brealey Publishing, London, Boston.

Shipton, H. and Defillippi, R. (2011), "Psychological perspectives in organizational learning: a fourquadrant approach", Handbook of Organizational Learning and Knowledge Management, Vol. 2, Wiley, Chichester, pp. 67-81, doi: 10.1002/9781119207245.ch4.

Siebenhüner, B. and Arnold, M. (2007), "Organizational learning to manage sustainable development", Business Strategy and the Environment, Vol. 16 No. 5, pp. 339-353, doi: 10.1002/bse.579. 
JWL 33,3

Singh, R.K., Murty, H.R., Gupta, S.K. and Dikshit, A.K. (2009), "An overview of sustainability assessment methodologies”, Ecological Indicators, Vol. 9 No. 2, pp. 189-212, doi: 10.1016/j. ecolind.2008.05.011.

Smith, P.A. (2012), "The importance of organizational learning for organizational sustainability", The Learning Organization, Vol. 19 No. 1, pp. 4-10, doi: 10.1108/09696471211199285.

Smith, P.A.C. and Sharicz, C. (2011), "The shift needed for sustainability", The Learning Organization, Vol. 18 No. 1, pp. 73-86, doi: 10.1108/09696471111096019.

Spillane, J.P. (2006), Distributed Leadership, Jossey-Bass, San Francisco, CA.

Toma, S.G. (2012), "A pilot study on the relationships among organizational learning, change, and sustainability in a responsible Romanian higher education institution", Amfiteatru Economic, Vol. 14, pp. 420-435.

Tsang, E.W. (1997), "Organizational learning and the learning organization: a dichotomy between descriptive and prescriptive research", Human Relations, Vol. 50 No. 1, pp. 73-89, doi: 10.1177/ 001872679705000104.

Tworek, K., Walecka-Jankowska, K. and Zgrzywa-Ziemak, A. (2019), "The role of information systems in shaping integrative logic for business sustainability", Operations Research and Decisions, Vol. 29 No. 4, pp. 125-146, doi: 10.37190/ord190406.

Ulrich, D., von Glinow, M.A. and Jick, T. (1993), "High impact learning: building and diffusing learning capability”, Organizational Dynamics, Vol. 22 No. 2, pp. 52-79, doi: 10.1016/0090-2616(93)90053-4.

Vallance, S., Perkins, H.C. and Dixon, J.E. (2011), "What is social sustainability? A clarification of concepts”, Geoforum, Vol. 42 No. 3, pp. 342-348, doi: 10.1016/j.geoforum.2011.01.002.

Velazquez, L.E., Esquer, J., Munguía, N.E. and Moure-Eraso, R. (2011), "Sustainable learning organizations", The Learning Organization, Vol. 18 No. 1, pp. 36-44, doi: 10.1108/09696471111095984.

Watkins, K.E. and Kim, K. (2018), "Current status and promising directions for research on the learning organization”, Human Resource Development Quarterly, Vol. 29 No. 1, pp. 15-29, doi: 10.1002/ hrdq.21293.

Wilson, J.P. and Beard, C. (2014), "Constructing a sustainable learning organization: Marks and Spencer's first plan a learning store”, The Learning Organization, Vol. 21 No. 2, pp. 98-112, doi: 10.1108/TLO-08-2012-0056.

Ya-Hui, S. and Li-Yia, F. (2008), "Assessing graduate attributes for employability in the context of lifelong learning: the holistic approach", Online Submission, Vol. 5 No. 11, pp. 1-10.

Yang, B., Watkins, K.E. and Marsick, V.J. (2004), "The construct of the learning organization: dimensions, measurement, and validation", Human Resource Development Quarterly, Vol. 75 No. 1, pp. 31-55, doi: 10.1002/hrdq.1086.

Zgrzywa-Ziemak, A. (2015), "The impact of organisational learning on organisational performance", Management and Business Administration. Central Europe, Vol. 23 No. 4, pp. 98-112, doi: 10.7206/mba.ce.2084-3356.159.

Zgrzywa-Ziemak, A. (2019a), "Organizational learning capability as a framework for business sustainability", Vision 2025: Education Excellence and Management of Innovations through Sustainable Economic Competitive Advantage, Proceedings of the 34th IBIMA Conference, Madrid, pp. 1791-1801.

Zgrzywa-Ziemak, A. (2019b), Model Zrównoważenia Przedsiębiorstwa [Business Sustainability Model], WUST Publishing House.

\section{Further reading}

Hung, R.Y.Y., Yang, B., Ya-Hui Lien, B., McLean, G.N. and Kuo, Y.-M. (2010), "Dynamic capability: impact of process alignment and organizational learning culture on perfornance", Journal of World Business, Vol. 45 No. 3, pp. 285-294, doi: 10.1016/j.jwb.2009.09.003. 
Table A1.

Mann-Whitney $U$ test statistics verifying the significance of differences in SP and organizational learning capability in

Polish and Danish companies 
JWL

33,3

178

\section{Appendix 2}

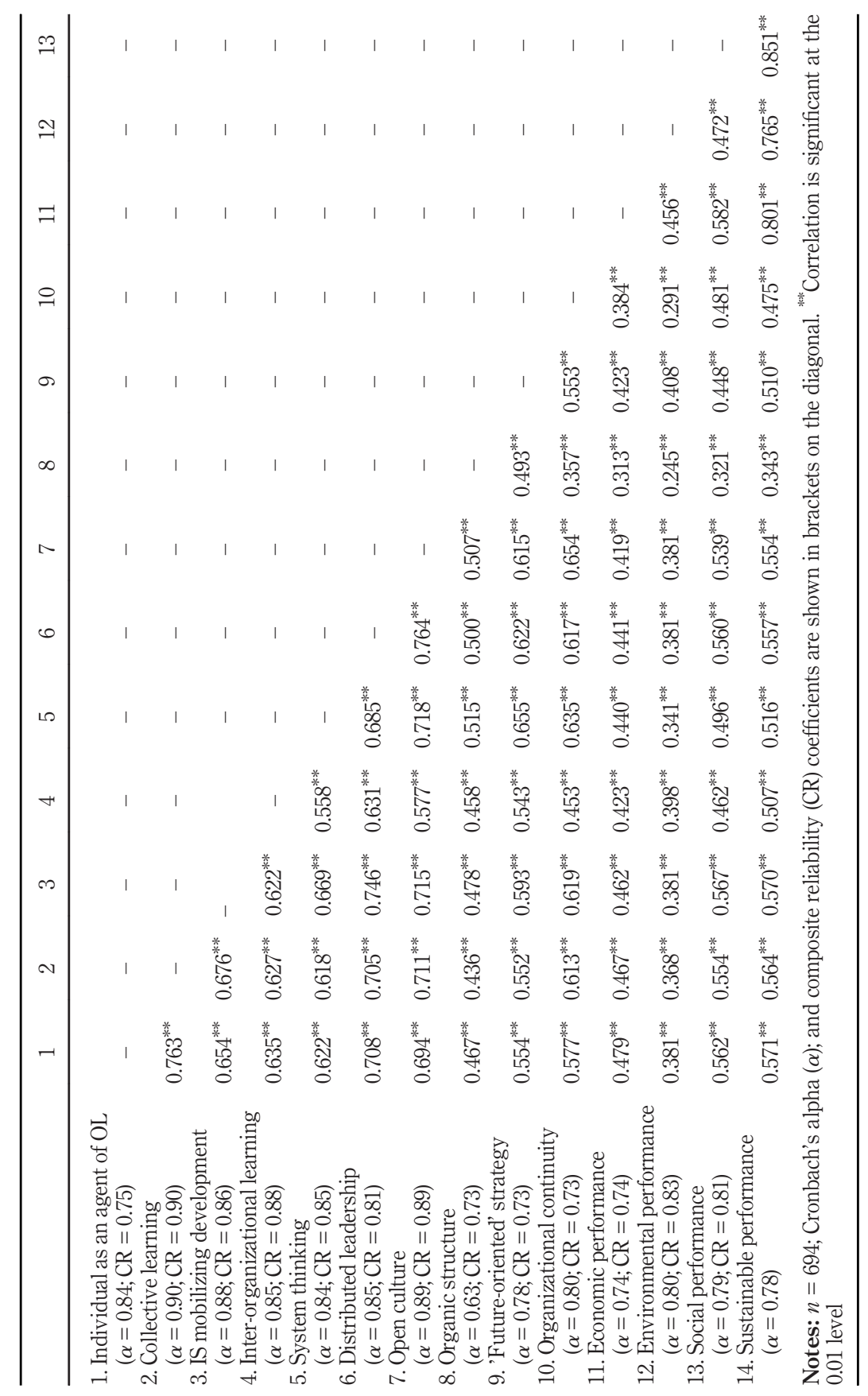

Table A2.

Model 1: Variables correlations and reliability coefficients 


\begin{tabular}{|c|c|c|c|c|c|c|c|c|c|}
\hline & 1 & 2 & 3 & 4 & 5 & 6 & 7 & 8 & \\
\hline \multicolumn{10}{|l|}{$\begin{array}{l}\text { 1. Individual as an agent } \\
\text { of OL }\end{array}$} \\
\hline \multirow{2}{*}{$\begin{array}{l}(\alpha=0.84 ; \mathrm{CR}=0.83) \\
\text { 2. Collective learning } \\
(\alpha=0.90 ; \mathrm{CR}=0.90) \\
\text { 3. IS mobilizing }\end{array}$} & - & - & - & - & - & - & - & - & 179 \\
\hline & \multicolumn{9}{|c|}{$\begin{array}{l}\text { 3. IS mobilizing } \\
\text { development }\end{array}$} \\
\hline $\begin{array}{l}\text { development } \\
(\alpha=0.88 ; \mathrm{CR}=0.86) \\
\text { 4. Inter-organizational }\end{array}$ & $0.654^{* *}$ & $0.676^{* *}$ & - & & - & - & - & - & \\
\hline $\begin{array}{l}\text { 4. Inter-organizational } \\
\text { learning } \\
(\alpha=0.85 ; \mathrm{CR}=0.88)\end{array}$ & $0.635^{* *}$ & $0.627^{* *}$ & $0.622^{* *}$ & - & - & - & - & - & \\
\hline & $0.622^{* *}$ & $0.618^{* *}$ & $0.669^{* *}$ & $0.558^{* *}$ & - & - & - & & \\
\hline \\
\hline $\begin{array}{l}\text { performance } \\
(\alpha=0.80 ; \mathrm{CR}=0.83)\end{array}$ & $0.381^{* *}$ & $0.368^{* *}$ & $0.381^{* *}$ & $0.398^{* *}$ & $0.341^{* *}$ & $0.456^{* *}$ & - & - & \\
\hline $\begin{array}{l}\text { 8. Social performance } \\
\quad(\alpha=0.79 ; \mathrm{CR}=0.81) \\
\text { 9. Sustainable }\end{array}$ & $0.562^{* *}$ & $0.554^{* *}$ & $0.567^{* *}$ & $0.462^{* *}$ & $0.496^{* *}$ & $0.582^{* *}$ & $0.472^{* *}$ & - & \\
\hline $\begin{array}{l}\text { performance } \\
(\alpha=0.78)\end{array}$ & $0.571^{* *}$ & $0.564^{* *}$ & $0.570^{* *}$ & $0.507^{* *}$ & $0.516^{* *}$ & $0.801^{* * *}$ & $0.765^{* *}$ & $0.851^{* *}$ & $\begin{array}{r}\text { Table A3. } \\
\text { Model 2: variables }\end{array}$ \\
\hline \multicolumn{10}{|c|}{$\begin{array}{l}\text { Notes: } n=694 \text {; Cronbach's alpha }(\alpha) \text {; and composite reliability (CR) coefficients are shown in brackets on } \begin{array}{r}\text { correlations and } \\
\text { the diagonal. }{ }^{* *} \text { Correlation is significant at the } 0.01 \text { level }\end{array}\end{array}$} \\
\hline
\end{tabular}

\section{Corresponding author}

Anna Zgrzywa-Ziemak can be contacted at: anna.zgrzywa-ziemak@pwr.edu.pl

For instructions on how to order reprints of this article, please visit our website: 